\title{
Determination of Ammonia Gas Safe Concentration in Chicken Farm Workers in Lembak Village, South Sumatra Indonesia
}

\author{
Putri Arianto ${ }^{1}$, Abdul Rohim Tualeka ${ }^{1}$, Desheila Andarini ${ }^{2}$, Pudji Rahmawati ${ }^{3}$, Syamsiar S Russeng ${ }^{4}$, Atjo \\ Wahyu ${ }^{4}$ \\ ${ }^{1}$ Department of Occupational Health and Safety, Public Health Faculty, Airlangga University, 60115, \\ Surabaya, East Java, Indonesia; ${ }^{2}$ Department of Occupational Health and Safety, Faculty of Public \\ Health, Sriwiijaya University, South Sumatra, Indonesia; ${ }^{3}$ Department of Development of Islamic Society, \\ State Islamic University Sunan Ampel, Surabaya, Indonesia; ${ }^{4}$ Department of Occupational Health and \\ Safety, Public Health Faculty, Hassanudin University, Makassar, Indonesia
}

\begin{abstract}
Ammonia is an alkaline gas with colorless and a strong odor characteristics. It can be formed naturally in the air, soil and water. Ammonia is also produced by humans and animals as part of normal biological processes. This study aims to determine the safe (C safe) concentration of ammonia gas in Chicken Farms in Lembak Village, South Sumatra Indonesia. This study was an observational with a sample of 14 chicken farm workers taken by purposive sampling. This study was analyzed based on primary and secondary data and processed through safe $\mathrm{C}$ calculations by determining the weight of experimental animals (W animals), body surface area of the experimental animal (BSA of experimental animals), workers' body weight (W), workers' body surface area (BSA), workers' breathing rate (BR), benzene concentration in the workplace (C), factor $\mathrm{Km}$ in animals (Animal $\mathrm{Km}$ ), factor $\mathrm{Km}$ in humans (Human $\mathrm{Km}$ ), highest dose of toxin without effect (NOAEL), and reference concentration of ammonia gas on workers (RfC).

The measurement results of the highest concentration of ammonia gas in the chicken farm around Lembak Selatan village, Sumatra was $0.006 \mathrm{mg} / \mathrm{m}^{3}(0.0086) \mathrm{ppm}$ and the average concentration of ammonia gas from 14 measurement points on the farm was $0.003214 \mathrm{mg} / \mathrm{m}^{3}(0.0046 \mathrm{ppm})$. The concentration level is below the threshold value set by PERMENAKER No. 5 of 2018, OSHA, NIOSH and ACGIH of 25 ppm. In contrast to these results, the manual calculation of safe ( $\mathrm{C}$ safe) concentration of ammonia gas was 0.022 $\mathrm{mg} / \mathrm{m}^{3}(0.031 \mathrm{ppm})$. With these results, the concentration of ammonia gas in the chicken farms of Desa Lembak Sumatera Selatan Indonesia is in the safe category. Nevertheless, prevention measures are needed to prevent the increase level of the gas.
\end{abstract}

Keywords: Ammonia gas, safe concentration, husbandry workers, husbandry

\section{Introduction}

Ammonia is an alkaline gas with characteristics of colorless and has a strong odor. About $80 \%$ of commercially produced ammonia is used in agricultural

\section{Corresponding Author:}

Abdul Rohim Tualeka

Department of Occupational Health and Safety,

Public Health Faculty, Airlangga University

Kampus C, Jalan Mulyorejo, Surabaya, 60115, Indonesia

Phone: +62 81333519732

Email: abdul-r-t@fkm.unair.ac.id fertilizers. ${ }^{2}$. Ammonia can be formed naturally in the air, soil and water. It is also produced by humans and animals as part of normal biological processes ${ }^{1}$. Animal husbandry contributes to the presence of dangerous ammonia in the environment that comes from the biological processes of animals in it. Ammonia is a constituent of animal feces and urine when nitrogen- 
rich proteins in feed are not fully converted into animal products such as meat, milk, wool, and eggs ${ }^{3}$.

Ammonia can react directly at certain levels of exposure. At a level of $5 \mathrm{ppm}$ it is almost undetectable. At $20 \mathrm{ppm}$ ammonia can have a different odor but can still be tolerated. $100 \mathrm{ppm}$ ammonia can now be very visible and somewhat uncomfortable when inhaled. At 500 ppm ammonia will irritate the throat, lungs, mucous membranes, skin and eyes that breathing equipment is needed at this level for exposure in a very short time. At $1000 \mathrm{ppm}$ or $0.1 \%$ ammonia becomes very toxic and a gas cartridge mask is required. At exposure rates above 2000 ppm, death can occur in less than 30 minutes $^{5}$.

Based on health effects and the dangers that can arise due to exposure to ammonia, various regulations regarding the threshold value of ammonia exposure have been made through careful calculations. OSHA, ACGIH, and NIOSH determined ammonia exposure to workers at a maximum of $25 \mathrm{ppm}$ with a duration of 8 hours and $35 \mathrm{ppm}$ for ammonia exposure for 15 minutes $^{6}$. Indonesia also regulates the threshold value of ammonia exposure which is equal to $25 \mathrm{ppm}$ or $17 \mathrm{mg} / \mathrm{m}^{3}$ through the Peraturan Menteri Ketenagakerjaan Number 5 of 2018 concerning Occupational Safety and Health at the Work Environment ${ }^{7}$.

This journal draws references from the research of Desheila et al (2017) on the Analysis of the Risk of Ammonia Gas Exposure to Chicken Farm Workers in Lembak Village, South Sumatra. The present study discusses Reference concentration of ammonia (NH3) of $0.028 \mathrm{mg} / \mathrm{kg} / \mathrm{day}$, real time intake of respondents in the range $0.0020(\mathrm{mg} / \mathrm{kg}) /$ day, and lifetime respondents' responses in the range of $0.7671(\mathrm{mg} / \mathrm{kg}) /$ day, as well as the risk received by respondents to exposure to ammonia gas $(\mathrm{RQ}<1)$. The previous research explained that the results of the measurement of ammonia gas concentrations in 14 average air sample points were $0.003214 \mathrm{mg} / \mathrm{m}^{3}$. Compared to the threshold value stated in PERMENAKER No. 5 of 2018, this level is still far below the threshold value of $25 \mathrm{ppm}$ or $17.41 \mathrm{mg} / \mathrm{m}^{38}$.

Previous research on the Analysis of Ammonia Gas Exposure Risks at Chicken Farm Workers in Lembak Village, South Sumatra, did not explain the safe limits of ammonia gas concentrations in chicken farm workers and Rfc calculations using No Observed Adverse Effect Level (NOAEL). In the present study, the authors calculated Rfc and safe concentration of exposure to ammonia gas in the air using No Observed Adverse Effect Level (NOAEL).

\section{Material and Method}

This study is an observational study which aimed to determine the safe concentration of exposure to ammonia gas in chicken farm workers in Lembak Village, South Sumatra. The study population was chicken farms in Lembak Village, the subject sample was chicken farm workers taken by purposive sampling which was 14 workers, and object samples was ammonia level in the chicken farm air. Data collection was carried out by interviews using questionnaires, weight measurements using scales, and direct measurement of ammonia concentration.

The variables of this study were the weight of experimental animals (W animals), body surface area of experimental animals (BSA of experimental animals), body weight (W), body surface area of workers (BSA), workers breathing rate (BR), ammonia gas concentration in workplace, $\mathrm{Km}$ enzen in animals (Animal $\mathrm{Km}$ ), Enzen $\mathrm{Km}$ in humans (Human $\mathrm{Km}$ ), highest dose of toxin without effect on experimental animals (NOAEL), enzene reference concentration on workers (RfC), and safe concentration of ammonia gas in air for workers (C is safe). Analysis of research data to determine the safe concentration of ammonia gas in the air for workers $(\mathrm{C}$ safe) was conducted manually.

\section{Result}

A. Characteristics and Surface Area of Experimental Animal Bodies: Toxicity testing of a compound is generally carried out using experimental animals. This is because the response to toxic compounds between humans and animals is similar. The experimental animals used in this study were white mice. Below is the table of characteristics and surface area of white rats as experimental animals:

\section{Table 1: Distribution of Characteristics of Experimental Animals (White Mice)}

\begin{tabular}{|c|c|c|}
\hline $\begin{array}{c}\text { Experimental animals } \\
\text { (white mice) }\end{array}$ & $\begin{array}{c}\mathbf{W} \\
\mathbf{( K g})\end{array}$ & $\begin{array}{c}\text { BSA } \\
\mathbf{( m}^{\mathbf{2}}\end{array}$ \\
\hline 1 & 0,1405 & 0,024165 \\
\hline 2 & 0,1405 & 0,024165 \\
\hline 3 & 0,1410 & 0,024223 \\
\hline 4 & 0,1410 & 0,024223 \\
\hline 5 & 0,1395 & 0,024050 \\
\hline 6 & 0,1415 & 0,024165 \\
\hline Average & 0,140667 & 0,024165 \\
\hline
\end{tabular}


The surface area of white mice is calculated using the following formula.

BSA $=0,09 W^{0,67}$

Where

BSA: Body Surface Area $\left(\mathrm{m}^{2}\right)$

$\mathrm{W}$ : Weight $(\mathrm{kg})$

B. Workers' Characteristics, Body Surface Area, and Respiratory Rate: As many as 14 workers of chicken farm in Lembak Selatan Selatan Village participated in this study with the lowest body weight of $14 \mathrm{~kg}$, the highest body weight of $75 \mathrm{~kg}$ and an average body weight of $51.85 \mathrm{~kg}$. Based on the results of the respondent's questionnaire, the exposure duration was 24 hours. This is because the workers stayed in the farm area that they were continuously exposed to ammonia gas produced by chickens. In the present study, the average height used was the average height of Indonesian adults of $159 \mathrm{~cm}$. Body surface areas and officer breathing rate were calculated by using the following formula.

\section{The average body surface area of the workers}

$\mathrm{BSA}=\sqrt{\mathrm{W} \cdot h / 3600}=\sqrt{51,85 \cdot 159 / 3600}=1,51\left(\mathrm{~m}^{2}\right)$

Where

BSA: Body Surface Area (m2)

W: Weight $(\mathrm{kg})$

h: Height (cm)

\section{Average workers' breathing rate}

$$
\begin{aligned}
\mathrm{BR} & =\frac{5,3 \ln \mathrm{W}-6,9}{24}=\frac{5,3 \ln 51,85-6,9}{24} \\
& =0,58 \mathrm{~m}^{3} / \mathrm{jam}
\end{aligned}
$$

where

$\mathrm{BR}$ : Breathing Rate ( $\mathrm{m}^{3} /$ hour)

$\mathrm{W}$ : Weight $(\mathrm{kg})$

Table 2: Distribution of Characteristics, Respiratory Rate, and duration of Working at Chicken Farm

\begin{tabular}{|c|c|c|c|c|c|}
\hline $\begin{array}{c}\text { Number } \\
\text { of } \\
\text { sample }\end{array}$ & $\begin{array}{c}\text { W } \\
(\mathrm{Kg})\end{array}$ & $\begin{array}{c}\text { h } \\
(\mathbf{c m})\end{array}$ & $\begin{array}{l}\text { BSA } \\
\left(\mathbf{m}^{2}\right)\end{array}$ & $\begin{array}{c}\mathrm{BR}\left(\mathbf{m}^{3} /\right. \\
\text { hour })\end{array}$ & $\begin{array}{c}\mathrm{t} \\
\text { (hour/ } \\
\text { day) }\end{array}$ \\
\hline 14 & 51,85 & 159 & 1,51 & 0,58 & 24 \\
\hline
\end{tabular}
Workers in Lembak Village, South Sumatra
Based on calculations carried out on chicken farm workers in Lembak Village, South Sumatra, the average body surface area of workers was 1.51 $\left(\mathrm{m}^{2}\right)$ and the respiratory rate of workers was 0.58 $\mathrm{m}^{3} /$ hour on average.

C. Concentration of Ammonia Gas: The highest concentration of ammonia gas in the chicken farm in Lembak South Sumatra is $0.006 \mathrm{mg} / \mathrm{m}^{3}(0.0086$ $\mathrm{ppm})$ and the average concentration of ammonia gas from 14 measurement points on chicken farms was $0.003214 \mathrm{mg} / \mathrm{m}^{3}$ (0.0046 ppm). The $\mathrm{mg} / \mathrm{m}^{3}$ conversion to ppm was calculated by the following formula.

$\mathrm{C}=24,45 \times \mathrm{C}(\mathrm{mg} / \mathrm{m} 3) \div$ molecular weight

Where:

$\mathrm{C}:$ Concentration in the air $(\mathrm{mg} / \mathrm{m} 3)$

MW : Molecular Weight Amonia $(17.031 \mathrm{~g} / \mathrm{mol})$

The highest $\mathrm{C}=24,45 \times 0,006 \mathrm{mg} / \mathrm{m}^{3} \div 17.031$

$$
=0,0086 \mathrm{ppm}
$$

$\mathrm{C}$ average $=24,45 \times 0.003214 \mathrm{mg} / \mathrm{m}^{3} \div 17.031$

$$
=0,0046 \mathrm{ppm}
$$

D. Animal Km and Human Km: Determination of animal $\mathrm{km}$ and human $\mathrm{km}$ is the first step in determining the safe limit of ammonia gas toxin dose. Calculation of animal $\mathrm{km}$ and human $\mathrm{km}$ are as follows:

\section{Animal km}

$$
\begin{aligned}
& \text { Animal } \mathrm{Km}=\frac{w \text { animal }}{\text { BSA animal }} \\
& \text { Where: }
\end{aligned}
$$

Animal Km: Km factor in experimental animals $\mathrm{W}$ : Weight $(\mathrm{kg})$

BSA : Body Surface Area (m2)

Table 3: Calculation Results of Animal Km in White Mice

\begin{tabular}{|c|c|c|c|}
\hline $\begin{array}{c}\text { Experimental } \\
\text { animal } \\
\text { (white mice) }\end{array}$ & $\begin{array}{c}\mathbf{W} \\
\mathbf{( K g )}\end{array}$ & $\begin{array}{c}\text { BSA } \\
\left.\mathbf{( m}^{\mathbf{2}}\right)\end{array}$ & $\begin{array}{c}\text { Animal Km } \\
\mathbf{( W / B S A )}\end{array}$ \\
\hline 1 & 0,1405 & 0,024165 & 5,814194082 \\
\hline 2 & 0,1405 & 0,024165 & 5,814194082 \\
\hline 3 & 0,1410 & 0,024223 & 5,820914007 \\
\hline
\end{tabular}


Conted...

\begin{tabular}{|c|c|c|c|}
\hline 4 & 0,1410 & 0,024223 & 5,820914007 \\
\hline 5 & 0,1395 & 0,024050 & 5,8004158 \\
\hline 6 & 0,1415 & 0,024165 & 5,855576247 \\
\hline Average & 0,1407 & 0,024165 & 5,82 \\
\hline
\end{tabular}

Based on the calculation of animal km above, the average animal $\mathrm{km}$ yield of chicken farm workers in Lebak Village, South Sumatra Indonesia is 5.82.

\section{Human km s}

Human $\mathrm{Km}=\frac{w \text { human }}{\text { BSA human }}$
Where

Human $\mathrm{Km}: \mathrm{Km}$ factor in humans

W : Weight $(\mathrm{kg})$

BSA : Body Surface Area $\left(\mathrm{m}^{2}\right)$

Table 4: Human Km Calculation Results for Chicken Farm Workers in Lembak Village, South Sumatra Indonesia

\begin{tabular}{|c|c|c|c|}
\hline $\begin{array}{c}\text { Number of } \\
\text { sample }\end{array}$ & $\begin{array}{c}\text { W } \\
(\mathbf{K g})\end{array}$ & $\begin{array}{c}\text { BSA } \\
(\mathbf{m} 2)\end{array}$ & $\begin{array}{c}\text { Human } \mathbf{K m} \\
\text { (W/BSA) }\end{array}$ \\
\hline 14 & 51,85 & 1,51 & 34,3 \\
\hline
\end{tabular}

The above human km calculation is obtained from the average body weight of the worker. Based on the above calculations the results of human $\mathrm{km}$ chicken farm workers in Lembak Sumatra Selatan Indonesia are 34.3.

E. No Observed Adverse Effect Level (NOAEL): NOAEL can be defined as the highest experimental point without side effects ${ }^{9}$. According to U.S. The Environmental Protection Agency (EPA), No Observed Adverse Effect Level (NOAEL) from ammonia is $4.9 \mathrm{mg} / \mathrm{m}^{3}(0.036 \mathrm{mg} / \mathrm{kg})$. Calculation of conversion from $\mathrm{mg} / \mathrm{m}^{3}$ to $\mathrm{mg} / \mathrm{kg}$ is as follows:

$$
\text { NOAEL ammonia } \begin{aligned}
\left(\mathrm{mg} / \mathrm{m}^{3}\right) & =\frac{4,9 \times 0,00013 \times 8}{0,1405} \\
& =0,036 \mathrm{mg} / \mathrm{kg}
\end{aligned}
$$

\section{F. Inhalation Reference Concentration (RfC):} Shaw et al. (2007) in Saridewi and Tualeka (2017) also explain that the determination of reference concentration on workers or the Inhalation Reference Concentration (RfC) can use the following formula ${ }^{12}$ :
$\mathrm{RfC}=\mathrm{NOAEL} \frac{\text { animal } \mathrm{Km}}{\text { human } \mathrm{Km}}$

Where:

RfC :Inhalation Reference Concentration (mg/kg)

Animal $\mathrm{Km}: \mathrm{Km}$ factor in experimental animals

Human $\mathrm{Km}: \mathrm{Km}$ factor in humans

Calculation of Inhalation Reference Concentration (RfC) obtained from the NOAEL value, Animal $\mathrm{Km}$ average, and the Human $\mathrm{Km}$ average shows the following results

$$
\begin{aligned}
\text { RfC } & =\text { NOAEL } \frac{\text { animal } \mathrm{Km}}{\text { human } \mathrm{Km}} \\
& =0,036 \frac{5,82}{34,3}=0,0061 \mathrm{mg} / \mathrm{kg}
\end{aligned}
$$

G. Safe Concentration of Ammonia Gas in Chicken Farm Workers in Lembak Village, South Sumatra Indonesia

The following is a safe $\mathrm{C}$ calculation with Rfc using No Observed Adverse Effect Level (NOAEL):

C safe $\left(\mathrm{mg} / \mathrm{m}^{3}\right)=\frac{(r f c)(\mathrm{W})}{(\delta)(\mathrm{BR})(t)}$

Where:

C safe : concentration of toxin in the air that is safe for the community $(\mathrm{mg} / \mathrm{m} 3)$

RfC : Inhalation Reference Concentration $(\mathrm{mg} / \mathrm{kg})$

W : Weight $(\mathrm{kg})$

$\delta: \%$ of substances absorbed by the lungs/if unknown then $100 \%{ }^{13}$

BR : Human breathing rate $\left(\mathrm{m}^{3} /\right.$ hour $)$

$\mathrm{t}$ : Working duration (hour)

MW : Molecular Weight

$$
\begin{aligned}
\text { Csafe }\left(\mathrm{mg} / \mathrm{m}^{3}\right) & =\frac{(r f c)(\mathrm{W})}{(\delta)(\mathrm{BR})(t)}=\frac{(0,0061)(51,85)}{(100 \%)(0,58)(24)} \\
& =0,022 \mathrm{mg} / \mathrm{m}^{3}
\end{aligned}
$$

In ppm, the conversion calculation is as follows

$$
\begin{aligned}
\text { C safe }(\mathrm{ppm}) & =\frac{\# m g / m 3 \times 24,45}{\text { molecular weight }}=\frac{0,022 \times 24,45}{17,031} \\
& =0,031 \mathrm{ppm}
\end{aligned}
$$


Based on the above calculations, the safe concentration of exposure to ammonia gas in Lembak village, West Sumatera Indonesia chicken farm workers is $0.022 \mathrm{mg} / \mathrm{m}^{3}(0.031 \mathrm{ppm})$.

\section{Discussion}

Determination of the safe concentration of ammonia gas in the chicken farm workers in Lembak South Sumatra Indonesia is based on calculations involving No Observed Adverse Effect Level (NOAEL) in it. No Observed Adverse Effect Level (NOAEL) used in this study came from U.S. The Environmental Protection Agency (EPA) is equal to $4.9 \mathrm{mg} / \mathrm{m}^{3}$ or equivalent to $0.036 \mathrm{mg} / \mathrm{kg}^{1}$. In the study conducted by Abdul Rohim Tualeka and Juliana Jalaludin (2018) by using white mice, it was determined that NOAEL ammonia was $0.0154 \mathrm{mg} / \mathrm{kg} /$ weight ${ }^{14}$. Another study by Abdul Rohim Tualeka, Jihan Faradisha and Rizky Maharja (2018) stated that NOAEL obtained from calculations with experimental animals was $0.0103 \mathrm{mg} / \mathrm{kg} /$ body weight ${ }^{10}$.

Calculation of Inhalation Reference Concentration (Rfc) was carried out by using NOAEL originating from U.S. The Environmental Protection Agency (EPA) shows value of $0.0061 \mathrm{mg} / \mathrm{kg}$. These results are smaller than that of ammonia gas Rfc found in previous studies on the Analysis of the Risk of Ammonia Gas Exposure to Chicken Farm Workers in Lembak Village, South Sumatra by $0.028 \mathrm{mg} / \mathrm{kg}$. The results of ammonia Rfc gas in the present study is higher than the chronic Rfc determined by U.S. Environmental Protection Agency (EPA) of $0.5 \mathrm{mg} / \mathrm{m}^{3}(0.0037 \mathrm{mg} / \mathrm{kg})$.

Based on the results of this study, the value of safe concentration of ammonia gas for chicken farm workers in Desa Lembak, South Sumatra Indonesia is $0.022 \mathrm{mg} /$ $\mathrm{m}^{3}(0.031 \mathrm{ppm})$. This value is higher than the average concentration of ammonia gas from 14 measurement points in Lembak Village farm in South Sumatra by $0.003214 \mathrm{mg} / \mathrm{m}^{3}(0.0046 \mathrm{ppm})$. The results explained that ammonia gas located in Lembak Village in South Sumatra Indonesia was safe for workers. The safe c value in this study is lower than that of OSHA,NIOSH, ACGIH, and Peraturan Menteri Ketenagakerjaan Number 5 of 2018 which determined ammonia exposure to workers at a maximum of $25 \mathrm{ppm}$.

\section{Conclusion and Recommendation}

Based on the results of this study, the value of safe concentration of ammonia gas for chicken farm workers in Desa Lembak, South Sumatra Indonesia is $0.022 \mathrm{mg} /$ $\mathrm{m}^{3}(0.031 \mathrm{ppm})$. This value is higher than the average concentration of ammonia gas from 14 measurement points in the Lembak Village farm in South Sumatra, which is $0.003214 \mathrm{mg} / \mathrm{m}^{3}(0.0046 \mathrm{ppm})$. Ammonia gas in the chicken farms of Desa Lembak, South Sumatra Indonesia is in safe category for workers.

While ammonia gas in the Lembak Village chicken farm is within safe concentration limits, an increase in the number of livestock will potentially increase the exposure of ammonia gas to workers. The presence of ammonia gas exposure is possible to disturb the comfort of workers and local residents. Therefore, it is necessary to attempt the use of personal protective equipment such as masks to reduce the level of ammonia gas inhalation for workers as well as cleaning livestock from urine and manure regularly and periodically. If it is possible, it is necessary to check regularly for checking the concentration of ammonia gas and checking the health of workers regularly.

Conflict of Interest: All authors have no conflicts of interest to declare.

Source of Funding: This is an article "Determination of Ammonia Gas Safe Concentration in Chicken Farm Workers in Lembak Village, South Sumatra Indonesia" of Occupational Health and Safety Department that was supported by Faculty of Public Health, Airlangga University.

Ethical Clearance: The study was approved by the institutional Ethical Board of the Public Health, Sriwijaya University.

\section{REFERENCE}

1. EPA. Toxicological review of ammonia (noncancer inhalation): executive summary. 2016;16(September):10. Available from: https://cfpub.epa.gov/ncea/iris/iris_documents/ documents/subst/0422_summary.pdf

2. U.S. Environmental Protection Agency. Toxicological review of ammonia (noncancer inhalation). Epa [Internet]. 2016;(September). Available from: https://cfpub.epa.gov/ncea/iris/ iris_documents/documents/toxreviews/0422tr.pdf 
3. Mikkelsen R. Ammonia emissions from agricultural operations: fertilizer. Better Crop [Internet]. 2009;93(4):9-11. Available from: http://www.nanc.ipni.net/ppiweb/ bcrops.nsf/\$webindex/8461612B20F2D0BE 85257690004D7C91/\$file/bc09-4p09.pdf

4. Agency for Toxic Substances and Disease Registry. TOXICOLOGICAL PROFILE FOR AMMONIA. 2004;(September).

5. LLC GAPS. AMMONIA HAZARDS. 2015;

6. OSHA. OSHA Annotated Table Z-1 [Internet]. 2018. Available from: https://www.osha.gov/dsg/ annotated-pels/tablez-1.html

7. Menteri Ketenagakerjaan Republik Indonesia. Peraturan Menteri Ketenagakerjaan Nomor 5 Tahun 2018. 2018.

8. Andarini D, Lestari M, Bahruddin M. ANALISIS RISIKO PAJANAN GAS AMONIA PADA PEKERJA PETERNAKAN AYAM DI DESA LEMBAK SUMATERA SELATAN. 2017;8(2):74-82.

9. Michael A. Dorato JAE. The no-observedadverse-effect-level in drug safety evaluations: Use, issues, and definition(s). In Elsevier; 2005. p. 265-74.
10. Tualeka AR, Faradisha J, Maharja R. Determination of No-Observed-Adverse-Effect Level Ammonia in White Mice Through CD4 Expression. Dose-Response. 2018;16(4):1-9.

11. Jakubowski M, Czerczak S. A proposal for calculating the no-observed-adverse-effect level (NOAEL) for organic compounds responsible for liver toxicity based on their physicochemical properties. Int J Occup Med Environ Health. 2014;27(4):627-40.

12. Tualeka AR. Toksikologi Industri \& Risk Assessment. Surabaya: Graha Ilmu Mulia; 2013.

13. Tualeka AR, Wibrata DA, Ahsan A, Rahmawati P, Russeng SS, Wahyu A. Determination of Highest Dose of Ammonia without Effect at Work Environment through the Expression of Interleukin-2 Cell in Rattus Novergicus. Open Access Maced J Med Sci. 2019;7(6):897-902.

14. Tualeka AR, Jalaludin J. Observation of Adverse Effect on Level Ammonia through Expression of CD8 Lymphocyte in Mice. Malaysian J Med Heal Sci. 2018; 